\title{
自律移動ロボット開発用ネットワーク分散システムの研究 A Development System for Autonomous Mobile Robot Using Distributing Network Technology
}

\author{
正 黒田洋司（明治大） ○ 三瓶元寛（明治大） \\ Yoji KURODA, Meiji University \\ Motohiro SANPEI, Meiji Uniersity
}

\begin{abstract}
This paper proposes a methodology of development for autonomous mobile robot. In recent year, more advanced capability is expected to the robot. For instance, a receptionist and guidance, cleaning of house, care and so on. They need a more advanced interaction with man. However, in order to realize it, in addition to control technology, we have to combine various and advanced technology, such as AI and an interface with man. Therefore, in future robot development, you have to attain the much more rationalization and the much more increase in efficiency. In this paper, the new robot development methodology using a developer's community, an open source, network technology, etc. is proposed.
\end{abstract}

Key Words: Mobile Robot, Distributing Network

\section{1. 緒言}

今日, ロボットは様々な分野への応用が期待され, 研究・ 開発，実証実験などが精力的に行われている。特に最近では， 病院や博物館での受付・案内や，一般家庭向けの介護や掃除 をするロボットなど，人間との自律的なインタラクションや 複雑な環境での自律移動技術を必要とする高度な分野への挑 戦が始まっている。

しかしながら，このような高度な自律ロボットを実現する ためには, 従来の制御理論に加えて, AI や人間とのインタフ エースに関する技術を統合する必要があり，限られた人員で の作業には手に余る規模になってきた.

こうした背景を受け，本国を含め幾つかの国においては， 国家的なプロジェクトとしてロボット関連技術の標準化が取 り組まれているが，未だ大きな成果は見られないのが現状で ある。

そこで本稿では，ロボット開発の現状を調査し，今後のロ ボット技術の発展を促進するために必要とされる開発基盤に ついて考察した。 またその上で，ネットワーク分散システム を利用したロボット開発基盤を提案する。

\section{2. ロボット開発の現状}

先に述べたように，これからのロボットには制御技術に加 えて $\mathrm{AI}$ やインタフェース等の様々な技術が必要であり，それ らの技術は個々に研究が進められている。ゆえに, 企業や大 学の枠を超え, 更には国家の枠を超えた技術共有が, これか らのロボット技術の発展の促進につながる.

ソフトウェアの共有を実現するためには，開発基盤の標準 化が求められる。そのような標準化に向けた取り組みは既に 存在し, 欧州の OROCOS[1]や米国の CLARAty[2], そして本 国の RT ミドルウェア[3]などが挙げられるが,それらは未だに 限られたコミュニティによる利用にとどまっている.

標準化が進まない原因として，企業や研究機関は既に個別 に開発基盤を確立しており，よほどのメリットが無い限り他 の技術を導入することに労力を割こうとはしない．特に企業 は自社の利益を追求しなければならない性質上，開発した技 術に関しては特許を取得し利益を独占するのが普通である。

\section{3. コミュニティの確立}

先に挙げたプロジェクト群は, まず標準化の仕様を決定し, さらにその標準に則ったプラットフォームを開発してから世 の中にアピールするという順序で進んでおり，そのように一 部の組織で決定された標準が簡単に国際的に受け入れられる とは考えにくい，RTミドルウェアはソフトウェア技術の国際 標準化団体 OMG を通して日本主導の国際標準化を目指して いるが,こちらもやはり他国の研究者が素直に日本主導の標 準に従うとは思えない。

すなわち，ソフトウェア基盤の国際的な標準化には，それ に賛同する大学やその他研究機関, 企業等による大規模なコ ミュニティの確立が先決である，そして，標準化はそのコミ ユニティの中で議論されるべきである.

\section{4. モジュール化とモジュールの共有}

ロボットのソフトウェアを機能要素にモジュール化するこ とは, CLARAtyやRTミドルウェアがすでに取り組んでおり, また，各研究機関が独自にモジュール化のシステムを作って いるケースも多い.

モジュール化すれば，開発作業を機能要素ごとに特化する ことができ，モジュールの構成によるシステムは自由度や拡 張性が高い。それゆえに，コミュニティによる技術共有もモ ジュール単位で行えれば理想的である。

しかしながら，様々な開発者が製作したモジュールを共有 する際の障壁となるのが，モジュール間の入出力のプロトコ ルやデータ型等のインタフェースの違いである。一つの研究 室内であれば，モジュールのインタフェースは開発者同士で 申し合わせておけげ問題は無いが，世界各地のモジュールを 共有するとなると，それは難しい，とはいえ，モジュールの インタフェースを細かく規定すると，ロボットの機能要素は 多岐に渡るため管理は難しく，また，開発の自由度も圧迫さ れ，開発者がコミュニティから離れていく原因にもなるだろ う.

このインタフェース問題について，次章でオープンソース による解決策を講じる。 


\section{5. オープンソース}

ソフトウェアの共有は，オープンソースという考え方が既 に技術者には定着している.オープンソースの成功例として, GNU プロジェクトが管理する Linux のオープンソースは世界 的に深く定着し，日々開発が進んでいる。さらにLinuxは，パ ッケージマネージャがソフトウェアパッケージ間の依存関係 を自動的に解決し，スムーズなインストールを実現している.

この Linux の機構をロボット開発にそのまま当てはめられ ないだろうか.ソフトウェアはモジュール単位で扱い，パッ ケージマネージャがモジュールのインタフェース関係を解決 すれば，モジュールの共有がスムーズに行われる。しかし， 多岐にわたるモジュールのインタフェース関係をどのように 解決するのかという問題が残っているように思われるが，才 一プンソースという性質上，モジュールは修正が重ねられ， 優れたモジュールが支持されることにより自然にインタフェ ースが統一されていくことが期待できる.

\section{6. ネットワーク分散システム}

本稿の題目でもあるネットワーク分散システムについて述 ベる.ここでのネットワーク分散の対象はモジュールである. 前章まではモジュール化はソフトウェアのオープンソース化 のための基盤として位置づけてきたが, 本研究では, モジュ 一ルによるネットワーク分散システムを形成し，モジュール の利用価值をさらに高める. 寸なわち, 本研究の全容は, ネ ットワーク分散モジュールを利用して, 研究者の国際的な協 調による開発の促進, システム開発・デバッグの効率化など, ロボットの開発を全面的に飛躍させることを目指寸ものであ る.

図 1 にモジュールのネットワークによって構成された自律 移動ロボットのシステムの例を示す.このようにモジュール をネットワーク化することで, システム構成の自由度や拡張 性の向上が図られる.

また， RTミドルウェアも同じくモジュールをネットワーク 分散することで, 異種ロボットや環境中に設置されたセンサ を繋ぎ，ロボットの環境認識精度の向上や人間への新しいサ 一ビスを模索している.

このようなモジュールのネットワークはもはや新しい概念 ではないが，本研究に掉いて新しく示すことは，分散モジュ 一ルをさらにロボットの開発基盤として有効に利用できると いうことである。

\section{1 センサデータの共有}

先の図 1 において，センサマネージャ層のモジュールは， センサの出力を一定周期で読み取り，その最新データを上層 モジュールの要求に応じて送信する働きをもつ. 図 1 ではど のモジュールも一つのモジュールとのみ接続しているが，実 際にはモジュールは複数のクライアントを受け付けることが できる、すなわち, センサマネージャ層のモジュールにより， センサデータをネットワーク経由で複数のモジュールで共有 することが可能である.

この特徴を利用すると，一台のロボットのセンサデータを ネットワーク上の複数のコンピュータで共有でき, 開発を並 行して行うことができる.

\section{2 仮想センサモジュール}

センサマネージャ層のモジュールで，実際のセンサ出力を 読む代わりに過去のログを読ませれば，過去の実験を再現す る形で，上位層のモジュールをデバッグすることができる.

また，センサマネージャ層をログではなく仮想空間とリン クさせることにより，上位層モジュールをそのままの形でシ ミュレーションすることができる．

このように，センサマネージャ層のモジュールを仮想セン サ用と実センサ用のどちらにアクセスするかを選択するだけ で，ロボットのシステムは仮想空間と実空間との間を自由に 行き来できるようになる，また，この仮想空間と実空間の切 り替えはモジュール単位で行うことができるため，シミュレ 一ションから実機テストへの移行を段階的に行うことができ る．例えば，レーザ測域センサのみを仮想センサにすれば， ロボットは見えない障害物（仮想笁間の障害物）を検知して それを回避するように動作する。このようなことが簡単に行 えることにより，より柔軟なデバッグが可能となる。

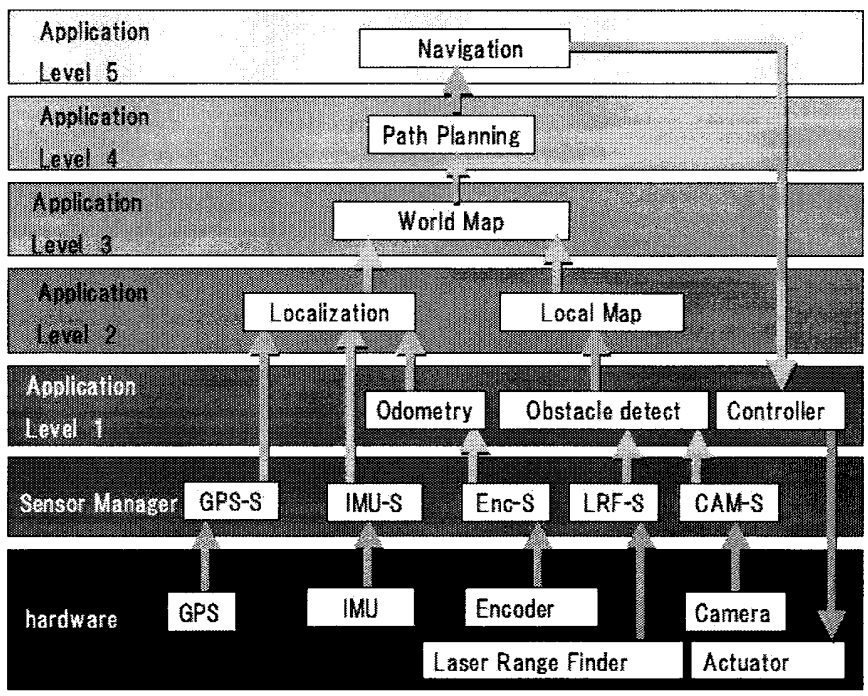

Fig 1. Module architecture for autonomous mobile robot

\section{7. 結言}

本研究では，人間と生活空間を共有できるような高度な自 律移動ロボットの実現には, 研究機関の国際的な連携が求め られることを示唆し，そのための基盤としてコミュニティの 形成やオープンソース，ネットワークを忍用した開発手法を 提案した.

\section{文 献}

[1] Herman, B., "Open Robot Control Software: the OROCOS project" IEEE Internationl Conference on Robotics \& Automation, 2001.

[2] Nesnas, Reid, S., Daniel, G., Clayton, K., Antonio D., Tara, E., Richard, M., John, G, Michael, M., I-Hsiang Shu \& David Apfelbaum "CLARAty: Challenges and Steps Toward Reusable Robotic Softwar"IEEE International Journal on Robotics and Automation, 2006

[3] Ando, N., Suehiro, T., Kitagaki, K., Kotoku, T. and Yoon, W "RT-Component Object Model in RT-Middleware," IEEE International Symposium on Computational Intelligence in Robotics and Automation, 2005 